\title{
Kualitas Organoleptik Kerupuk Kulit Kaki Ayam yang Diproduksi dari Jenis Ras Ayam dan Larutan Perendam Berbeda
}

\author{
Organoleptic Quality of Chicken Shank Skin Crackers Produced from Different Chicken \\ Types and Marinate Solutions
}

\section{Muhammad Irfan Said, Effendi Abustam, Arifuddin}

\author{
Program Studi Teknologi Hasil Ternak, Fakultas Peternakan Universitas Hasanuddin \\ Jl. Perintis Kemerdekaan Km.10 Kampus Unhas Tamalanrea, Makassar 90245 \\ email : irfanmks@yahoo.com HP 08124206293
}

\begin{abstract}
Crackers is one of food products that is in high demand by society lately. Crackers made from chicken shank skin is processed by utilizing by-product of chicken slaughter. This study was aimed to determine the organoleptic quality of crackers made from chicken shank skin that were produced based on different types and marinade solutions. Completely randomized design (CRD) with factorial pattern of $3 \times 2 \times 3$ was used in this study. There were two factors were applied, namely : factor I was three types of chicken (broiler, layer and native). Factor II were two types of marinate solution, acid $\left(\mathrm{CH}_{3} \mathrm{COOH} 1 \%\right)(\mathrm{v} / \mathrm{v})$ and bases $\left(\mathrm{Ca}(\mathrm{OH})_{2} 1 \%\right)$ $(\mathrm{w} / \mathrm{v})$, each treatment was repeated 3 times. The scale system from panelists was used to obtain the data, then analyzed for variance (ANOVA). Results of this study showed that different types of chicken very significantly affected $(\mathrm{P}<0.01)$ on the appearance of skin color and acceptance based on consumer perceptions, but had no effect $(\mathrm{P}>0.05)$ on odor, taste and crunchiness. The different types of marinade solution has significant effect $(\mathrm{P}<0.05)$ on taste, but it had no effect $(\mathrm{P}>0.05)$ on odor, crunchiness and acceptance. Generally, panelists gave the best acceptance on crackers made of broiler shank skin soaked in bases $\left(\mathrm{Ca}(\mathrm{OH})_{2} 1 \%(\mathrm{w} / \mathrm{v})\right.$.
\end{abstract}

Keywords : organoleptic quality, crackers, shank skin, marinate solution

\begin{abstract}
ABSTRAK
Kerupuk merupakan salah satu jenis produk makanan yang banyak diminati oleh masyarakat saat ini. Kerupuk dari kulit kaki ayam merupakan produk olahan asal ternak yang memanfaatkan hasil ikutan dari pemotongan ayam. Penelitian ini bertujuan untuk mengetahui kualitas kerupuk dari kulit kaki ayam yang diproduksi menggunakan jenis larutan perendam dan ras ayam berbeda. Penelitian dilaksanakan secara eksperimen laboratorium menggunakan rancangan acak lengkap (RAL) pola faktorial 3x2x3. Faktor I adalah bahan baku dari 3 jenis ras ayam (ras pedaging; ras petelur dan buras). Faktor II adalah 2 jenis larutan perendam (asam $\left(\mathrm{CH}_{3} \mathrm{COOH} 1 \% \mathrm{v} / \mathrm{v}\right)$ dan basa $\left(\mathrm{Ca}(\mathrm{OH})_{2} 1 \% \mathrm{~b} / \mathrm{v}\right)$, masing-masing perlakuan diulang 3 kali. Data pengamatan diperoleh dengan menggunakan sistem skala yang dilakukan oleh panelis. Data diperoleh selanjutnya dianalisis secara sidik ragam. Hasil penelitian menunjukkan bahwa perbedaan jenis ras ayam berpengaruh sangat nyata $(\mathrm{P}<0,01)$ terhadap penampilan warna maupun kesukaan kerupuk kulit berdasarkan persepsi konsumen, namun tidak berpengaruh $(\mathrm{P}>0,05)$ pada bau, cita rasa dan kerenyahan. Perbedaan jenis bahan perendam berpengaruh nyata $(\mathrm{P}<0,05)$ terhadap cita rasa, namun tidak berpengaruh $(\mathrm{P}>0,05)$ terhadap persepsi bau, kerenyahan dan kesukaan kerupuk kulit. Secara umum panelis memberikan persepsi lebih baik pada produk kerupuk kulit yang diproduksi dari bahan baku kulit kaki ayam ras pedaging yang direndam dalam larutan basa $\left(\mathrm{Ca}(\mathrm{OH})_{2} 1 \% \mathrm{~b} / \mathrm{v}\right)$.
\end{abstract}

Kata kunci : kualitas organoleptik, kerupuk, kulit kaki ayam, larutan perendam

\section{PENDAHULUAN}

Seiring dengan bertambahnya jumlah penduduk, maka tentunya kebutuhan masyarakat akan pangan juga cenderung akan meningkat. Kebutuhan pangan dapat terpenuhi melalui suplai pangan hewani maupun nabati. Sumber pangan hewani dapat berasal dari ternak maupun ikan. Sumber pangan hewani asal ternak yang berkembang pesat akhir-akhir ini adalah unggas, dengan populasi melebihi ternak lainnya seperti sapi, 
kerbau, kambing, maupun domba.

Berdasarkan data Kementerian Pertanian RI, populasi unggas khususnya ayam pada tahun 2011 di Indonesia telah mencapai 1.566.966.297 ekor, yang terdiri atas ayam ras pedaging (1.177.990.869 ekor), ayam ras petelur (124.635.794 ekor), dan ayam buras (264.339.634 ekor) (Anonimus, 2012). Salah satu keunggulan ternak unggas dibandingkan dengan ternak lain adalah karena unggas khususnya ayam, hampir sebagian besar tubuhnya dapat dimanfaatkan untuk kebutuhan manusia. Hasil ikutan seperti feses dimanfaatkan untuk kompos, bulu untuk industri kerajinan dan bahan pakan ternak, tulang sebagai sumber gelatin dan bahan pakan ternak serta kulit pada bagian kakinya dapat dimanfaatkan sebagai bahan baku pembuatan kerupuk kulit.

Kerupuk kulit atau rambak merupakan makanan ringan yang khas dan memiliki nilai gizi yang hampir sama dengan daging ayam, karena kaki ayam sebenarnya terdiri atas daging dan kulit. Komposisi nilai gizi kulit kaki ayam, terdiri dari air sebanyak $66 \%$, protein $22 \%$, lemak $5,5 \%$, abu $3,5 \%$, dan substansi lain (kalori, fosfor, kalsium, zat besi, vitamin A dan vitamin B1) $\pm 3 \%$ (Purnomo, 1992).

Bagian kulit kaki pada ayam sebagian besar terdiri atas protein kolagen. Secara histologis kulit terbagi atas 3 bagian, yakni epidermis, dermis/korium serta hipodermis. Proses pembentukan kerupuk terkait dengan mekanisme penguraian dan hidrolisis ikatan serabut kolagen pada kulit. Ikatan serabut kolagen khususnya pada bagian lapisan dermis/korium kulit yang mendapat pengaruh panas, maka ikatan serabut tersebut akan mengalami proses denaturasi (Muyonga et al., 2003).

Kualitas produk kerupuk kulit dipengaruhi oleh beberapa faktor, salah satu diantaranya adalah sumber bahan baku maupun proses produksi. Bahan baku akan mempengaruhi struktur dan komposisi produk akhir. Proses produksi melibatkan berbagai proses reaksi yang akan berpengaruh secara langsung terhadap kualitas dalam hal ini secara fisik, kimia maupun organoleptik. Penggunaan bahan kimia jenis asam dapat dimanfaatkan untuk meningkatkan kelarutan protein yang diharapkan akan memperbaiki sifat-sifat kerupuk kulit (Verheul, 1998). Kualitas dan penampilan produk kerupuk kulit sangat menentukan daya terima konsumen. Penelitian ini bertujuan untuk mengetahui kualitas organoleptik produk kerupuk kulit yang diproduksi dari bahan baku kulit kaki ayam dengan menerapkan perbedaan jenis ras ayam dan bahan perendam.

\section{MATERI DAN METODE}

Penelitian dilaksanakan di Laboratorium Teknologi Hasil Ternak Fakultas Peternakan Universitas Hasanuddin, Makassar. Materi utama penelitian ini berupa potongan kaki yang diperoleh dari tiga jenis ras ayam, yaitu ayam pedaging (broiler), ras petelur (layer) dan bukan ras (buras)/ayam kampung (native chicken), larutan asam asetat $\left(\mathrm{CH}_{3} \mathrm{COOH}\right) 1 \%(\mathrm{v} / \mathrm{v})$ dan larutan basa $\left(\mathrm{Ca}(\mathrm{OH})_{2}\right) 1 \%(\mathrm{~b} / \mathrm{v})$, aquades, minyak goreng, bumbu-bumbu berupa bawang putih, merica, ketumbar, garam, dan 
penyedap rasa. Peralatan pendukung yang digunakan diantaranya : tang pemisah kulit dan tulang, pisau cutter, gunting, baskom, timbangan analitik, wadah, panci kukusan, wajan, kompor, talenan, dan kertas label.

\section{Rancangan Penelitian dan Penentuan Sampel}

Penelitian dilakukan secara eksperimen laboratorium dengan menggunakan rancangan dasar berupa Rancangan Acak Lengkap (RAL) Pola Faktorial $3 \times 2$ dengan 3 kali ulangan. Faktor I, 3 jenis ras ayam (ras pedaging, petelur dan buras). Faktor II, 2 jenis larutan perendam (asam $\left(\mathrm{CH}_{3} \mathrm{COOH}\right) 1 \%$ $\mathrm{v} / \mathrm{v}$ dan basa $\left(\mathrm{Ca}(\mathrm{OH})_{2} \quad 1 \% \quad \mathrm{~b} / \mathrm{v}\right)$. Pengambilan data deskriptif terkait dengan pengujian warna, bau, cita rasa, kerenyahan, dan kesukaan (hedonik) menggunakan 10 orang panelis yang dipilih dari mahasiswa fakultas peternakan. Sebelum pengambilan data, terlebih dahulu dilakukan sosialisasi kepada para panelis untuk menyamakan persepsi dalam proses penilaian. Pengisian lembar isian dilakukan setelah para panelis melakukan pengujian.

Metode penilaian organoleptik dilakukan dengan menggunakan sistem skala. Skala yang digunakan dalam penilaian panelis adalah 1-6 untuk setiap parameter. Penilaian warna menggunakan skala 1-6 (coklat tua-putih), bau menggunakan skala 1-6 (tidak ada bau khas kerupuk-bau khas kerupuk), cita rasa menggunakan skala 1-6 (tidak gurih-sangat gurih), kerenyahan menggunakan skala 1-6 (tidak renyah-sangat renyah), kesukaan menggunakan skala 1-6 (tidak suka-sangat suka).

\section{Pembuatan Larutan Perendam}

Larutan perendam $\mathrm{CH}_{3} \mathrm{COOH}$ dan $\mathrm{Ca}(\mathrm{OH})_{2}$ masing-masing $1 \%$ dibuat dengan melarutkan larutan dasar $\left(\mathrm{CH}_{3} \mathrm{COOH}\right.$ dan $\left.\mathrm{Ca}(\mathrm{OH})_{2}\right)$ dalam aquades. Larutan perendam $\mathrm{CH}_{3} \mathrm{COOH} 1 \% \quad(\mathrm{v} / \mathrm{v})$ dibuat dengan melarutkan $10 \mathrm{ml}$ larutan $\mathrm{CH}_{3} \mathrm{COOH}$ teknis dengan konsentrasi $5 \%$ dengan aquades hingga mencapai volume 1 liter, sedangkan $\mathrm{Ca}(\mathrm{OH})_{2} 1 \%$ (b/v) dibuat dengan melarutkan $10 \mathrm{~g}$ serbuk $\mathrm{Ca}(\mathrm{OH})_{2}$ teknis dengan aquades hingga mencapai volume 1 liter. Larutan ini selanjutnya digunakan sebagai larutan perendam dalam proses produksi kerupuk kulit kaki ayam.

\section{Proses Produksi Kerupuk Kulit}

Bahan baku berupa kaki (shank) ayam segar khususnya pada potongan tulang kaki bawah (os tarso-metatarsus) yang diperoleh dari 3 jenis ras ayam (pedaging, petelur dan buras) dicuci dengan air mengalir. Pemisahan antara kulit dan tulang kaki dilakukan dengan menggunakan pisau cutter dengan mengiris secara vertikal yang dimulai dari bagian telapak. Kulit kemudian ditarik dengan alat berupa tang. Kulit kaki yang telah terpisah lalu ditimbang, selanjutnya dicuci kembali dengan air mengalir dan kemudian dilakukan perendaman dalam 2 jenis larutan $\left(\mathrm{CH}_{3} \mathrm{COOH}\right)$ dan $\left.\mathrm{Ca}(\mathrm{OH})_{2}\right)$ masing-masing selama 60 menit. Kulit kaki diberi bumbu sebanyak $1 \%$ dari berat kulit dan didiamkan selama \pm 15 menit. Proses dilanjutkan dengan pengukusan selama \pm 15 menit hingga kulit berubah warna. Kulit dikeringkan dalam oven suhu $60^{\circ} \mathrm{C}$ selama 2-3 jam hingga kulit kaki mengeras. Proses dilanjutkan 
dengan penggorengan dalam minyak mendidih (suhu $\pm 120^{\circ} \mathrm{C}$ ) hingga kulit terlihat mekar dan selanjutnya didinginkan untuk dilakukan uji kualitas.

Paramater pengamatan dilakukan secara deskriptif meliputi warna (color), bau (odor), cita rasa (taste), kerenyahan (crunchiness) serta secara hedonik yakni tingkat kesukaan (likeness) (Soekarto dan Hubeis, 1993). Data skala yang telah ditabulasi berdasarkan penilaian panelis selanjutnya dianalisis secara sidik ragam berdasarkan Rancangan Acak Lengkap (RAL) Pola Faktorial. Hasil uji yang menunjukan pengaruh nyata, selanjutnya dilakukan uji lanjut dengan uji BNT (Beda Nyata Terkecil) (Gasperz, 1991)

\section{HASIL DAN PEMBAHASAN}

\section{Warna}

Warna merupakan penilaian pertama terhadap produk yang akan diuji secara visual. Penampakan warna produk sangat mempengaruhi minat konsumen/penelis, karena warna suatu produk penganan dapat membangkitkan selera konsumen. Data hasil penilaian panelis terhadap penampilan warna kerupuk kulit kaki ayam pada penerapan jenis ras ayam dan larutan perendaman yang berbeda disajikan pada Tabel 1 .

Hasil analisis ragam terhadap data pada Tabel 1 menunjukkan bahwa perbedaan jenis ras ayam dan larutan perendam berpengaruh sangat nyata $(\mathrm{P}<0,01)$ terhadap penampilan warna produk kerupuk kulit kaki ayam. Secara rata-rata persepsi panelis terhadap warna produk kerupuk kulit berada pada skala 25. Perbedaan jenis ras ayam akan memberikan komposisi dan struktur protein kolagen yang berbeda dalam kaitannya dengan umur dan strain ayam, sedangkan larutan perendam berperan untuk merubah struktur jaringan kulit khususnya serabut kolagen pada kulit kaki ayam. pH larutan berpengaruh terhadap kelarutan kolagen (Wang et al., 2008). Struktur jaringan kulit berpengaruh terhadap sifat-sifat fisik kulit khususnya serabut kolagen. Serabut kolagen mudah berekasi dengan asam dan basa (amphoter) (Budiyanto, 1984).

Tabel 1. Nilai Rata-Rata Hasil Penilaian Warna Kerupuk Kulit Kaki Ayam

\begin{tabular}{lccc}
\hline \multirow{2}{*}{ Jenis Ras Ayam } & \multicolumn{2}{c}{ Penilaian Warna Menggunakan Jenis Larutan Perendam } & \multirow{2}{*}{ Rata-rata } \\
\cline { 2 - 3 } & $\mathrm{CH}_{3} \mathrm{COOH} 1 \%(\mathrm{v} / \mathrm{v})$ & $\mathrm{Ca}(\mathrm{OH})_{2} 1 \%(\mathrm{~b} / \mathrm{v})$ & \\
\hline Pedaging (broiler) & 3,66 & 5,22 & $4,44^{\mathrm{c}}$ \\
Petelur (layer) & 2,09 & 4,07 & $3,08^{\mathrm{a}}$ \\
Buras & 2,09 & 5,16 & $3,62^{\mathrm{b}}$ \\
\hline \multicolumn{1}{c}{ Rata-rata } & $2,61^{\mathrm{a}}$ & $4,82^{\mathrm{b}}$ & \\
\hline
\end{tabular}

Keterangan: Skala penilaian warna : 1-6 (coklat tua-putih). Huruf yang berbeda pada kolom dan baris yang sama menunjukkan perbedaan yang sangat nyata $(\mathrm{P}<0,01)$

Penampilan warna kerupuk kulit kaki ayam yang direndam dalam larutan asam $\left(\mathrm{CH}_{3} \mathrm{COOH}\right)$ cenderung memberikan warna kecoklatan, sedangkan larutan basa $\left(\mathrm{Ca}(\mathrm{OH})_{2}\right)$ cenderung memberikan warna putih. Hasil yang diperoleh kemungkinan terkait pula dengan warna dasar dari kulit kaki ayam, yakni ayam buras berwarna coklat sampai kehitaman, pedaging berwarna putih dan petelur berwarna agak 
kecoklatan. Penampilan warna kerupuk kulit kaki ayam yang kecoklatan dapat dipengaruhi oleh sifat asam yang lebih kuat. Sifat asam memiliki kemampuan yang kuat dalam melonggarkan jaringan ikat dibandingkan dengan sifat basa. Asam memecah ikatan kolagen menjadi struktur monoheliks, sedangkan basa hanya memecah sampai batas biheliks (Zhang et al., 2007). Penampilan warna coklat pada kerupuk pada dasarnya merupakan fenomena reaksi Maillard. Reaksi ini terkait oleh adanya peningkatan suhu dan perubahan $\mathrm{pH}$ (asam atau basa) (Tyler and Gregory, 2005). Reaksi pencoklatan merupakan reaksi non enzimatis yang terjadi karena adanya gugus aldehid dari karbohidrat yang saling bereaksi dengan gugus amino dari protein pada suhu. Reaksi ini memberikan perubahan biologis yang sangat kompleks, salah satunya berperan dalam menampilkan warna, rasa, aroma dan tekstur pada pangan (Son et al., 2000).

Hasil penelitian Emil (2004), menunjukkan bahwa semakin lama waktu perendaman kulit kaki ayam dalam larutan asam, maka penampilan warna akan semakin gelap, dan sebaliknya perendaman kulit dalam larutan kapur menunjukkan penampilan warna yang semakin cerah. Kualitas warna kerupuk kulit kaki ayam yang dihasilkan dengan menggunakan jenis larutan perendam basa telah memenuhi syarat Standar Nasional Indonesia (SNI) 01-4308-1996 dalam hal ini berwarna normal.

\section{Bau}

Hasil penilaian panelis terhadap bau dari produk kerupuk kulit kaki ayam yang menggunakan bahan baku dari jenis ras dan larutan perendam berbeda disajikan pada Tabel 2.

Tabel 2. Nilai Rata-Rata Hasil Penilaian Bau Kerupuk Kulit Kaki Ayam

\begin{tabular}{|c|c|c|c|}
\hline \multirow{2}{*}{ Jenis Ras Ayam } & \multicolumn{2}{|c|}{ Penilaian Bau Menggunakan Jenis Larutan Perendam } & \multirow{2}{*}{ Rata-rata } \\
\hline & $\mathrm{CH}_{3} \mathrm{COOH} 1 \%(\mathrm{v} / \mathrm{v})$ & $\mathrm{Ca}(\mathrm{OH})_{2} 1 \%(\mathrm{~b} / \mathrm{v})$ & \\
\hline Pedaging (broiler) & 4,09 & 4,55 & 4,32 \\
\hline Petelur (layer) & 4,37 & 4,24 & 4,31 \\
\hline Buras & 4,37 & 4,49 & 4,43 \\
\hline Rata-rata & 4,28 & 4,43 & \\
\hline
\end{tabular}

Keterangan: Skala penilaian bau : 1-6 (tidak ada bau khas kerupuk- bau khas kerupuk)

Hasil analisis ragam pada Tabel 2 menunjukkan bahwa perbedaan jenis ras ayam dan larutan perendam dalam proses produksi kerupuk kulit kaki ayam tidak menunjukkan pengaruh yang nyata $(\mathrm{P}>0,05)$ terhadap bau kerupuk yang dihasilkan. Hasil penilaian panelis terhadap bau produk kerupuk kulit secara rata-rata berada pada kisaran skala 4 . Penilaian tersebut apabila dipersepsikan maka bau yang dihasilkan berada pada kategori sedang (terdapat bau kerupuk). Tidak adanya perbedaan bau berdasarkan penilaian panelis dari setiap perlakuan yang diberikan dapat disebabkan oleh pengaruh pemberian bumbu selama proses produksi. Rempah-rempah yang digunakan dalam proses pembuatan kerupuk kulit dapat menghilangkan bau anyir pada kaki ayam (Sutejo dan Damayanti, 2002). Berdasarkan syarat mutu SNI, kualitas bau kerupuk kulit kaki ayam masih sesuai 
dengan syarat mutu SNI 01-4308-1996, yang diproduksi berdasarkan perbedaan yaitu berbau normal (khas kerupuk kulit).

\section{Cita-rasa} jenis ras ayam dan larutan perendam

Hasil penilaian panelis terhadap cita rasa produk kerupuk kulit kaki ayam

Tabel 3. Nilai Rata-Rata Hasil Penilaian Cita Rasa Kerupuk Kulit Kaki Ayam

\begin{tabular}{|c|c|c|c|}
\hline \multirow{3}{*}{ Jenis Ras Ayam } & \multicolumn{2}{|c|}{ Penilaian Cita Rasa Menggunakan Jenis Larutan } & \multirow{3}{*}{ Rata-rata } \\
\hline & \multicolumn{2}{|c|}{ Perendam } & \\
\hline & $\mathrm{CH}_{3} \mathrm{COOH} 1 \%(\mathrm{v} / \mathrm{v})$ & $\mathrm{Ca}(\mathrm{OH})_{2} 1 \%(\mathrm{~b} / \mathrm{v})$ & \\
\hline Pedaging (broiler) & 3,18 & 5,16 & 4,17 \\
\hline Petelur (layer) & 3,61 & 4,74 & 4,17 \\
\hline Buras & 3,61 & 5,10 & 4,36 \\
\hline Rata-rata & $3,47^{\mathrm{a}}$ & $5,00^{\mathrm{b}}$ & \\
\hline
\end{tabular}

Tabel 3 menunjukkan bahwa penerapan jenis ras ayam yang berbeda tidak memiliki pengaruh yang nyata $(\mathrm{P}>0,05)$ sedangkan penerapan jenis bahan perendam yang berbeda memiliki pengaruh yang sangat nyata $(\mathrm{P}<0,01)$ terhadap cita rasa produk kerupuk kulit berbahan baku kulit kaki ayam.

Hasil penilaian panelis terhadap cita rasa produk kerupuk kulit kaki ayam secara rata-rata berada pada kisaran nilai 35. Terjadinya perbedaan persepsi ini kemungkinan dipengaruhi oleh masih adanya rasa asam yang terikut pada produk kerupuk saat dilakukan proses perendaman. Pemberian larutan basa (kapur) pada kulit tidak akan memberikan perubahan yang nyata pada permukaan kulit. Persepsi panelis terhadap rasa gurih pada produk kerupuk kaki ayam dapat dipengaruhi oleh adanya penambahan bumbu saat diproses. Racikan bumbu berperan dalam menambah cita rasa dari suatu produk penganan.

Bumbu selain sebagai berperan menghilangkan bau anyir juga, juga yang paling penting adalah sebagai pemberi rasa dan penambah kelezatan pada kerupuk. Bawang putih digunakan sebagai pelengkap bumbu yang mampu memberikan rasa sedap dan gurih pada kerupuk. Penambahan garam dilakukan untuk memberikan rasa gurih dan rasa asin, selain itu juga berperan dalam menghambat pertumbuhan mikroorganisme (Sutejo dan Damayanti, 2002).

\section{Kerenyahan}

Kerenyahan merupakan tolak ukur penilaian yang utama untuk jenis pangan yang berbentuk kerupuk. Hasil penilaian panelis terkait dengan sifat kerenyahan produk kerupuk berbahan baku kulit kaki ayam selengkapnya disajikan pada Tabel 4.

Berdasarkan hasil analisis ragam terhadap data pada Tabel 4 menunjukkan bahwa perbedaan jenis ras ayam maupun larutan perendam dalam proses produksi tidak memiliki pengaruh yang nyata $(\mathrm{P}>0,05)$ terhadap sifat kerenyahan produk kerupuk berbahan baku kulit kaki ayam. Secara umum penilaian panelis terhadap produk berada pada penilaian skala 5 
(mendekati sifat sangat renyah). Tidak adanya perbedaan yang nyata dari setiap perlakuan dapat disebabkan oleh adanya kemiripan struktur penyusun kulit berupa kolagen dari setiap bahan yang digunakan.

Tabel 4. Nilai Rata-Rata Hasil Penilaian Kerenyahan Kerupuk Kulit Kaki Ayam

\begin{tabular}{lccc}
\hline \multirow{2}{*}{ Jenis Ras Ayam } & \multicolumn{2}{c}{ Penilaian Kerenyahan Menggunakan Jenis Larutan Perendam } & \multirow{2}{*}{ Rata-rata } \\
\cline { 2 - 3 } & $\mathrm{CH}_{3} \mathrm{COOH} 1 \%(\mathrm{v} / \mathrm{v})$ & $\mathrm{Ca}(\mathrm{OH})_{2} 1 \%(\mathrm{~b} / \mathrm{v})$ & 5,24 \\
\hline Pedaging (broiler) & 5,33 & 5,16 & 5,16 \\
Petelur (layer) & 5,28 & 5,04 & 5,25 \\
Buras & 5,28 & 5,22 & 5,14 \\
\hline \multicolumn{1}{c}{ Rata-rata } & 5,28 & & \\
\hline
\end{tabular}

Keterangan: Skala penilaian kerenyahan : 1-6 (tidak renyah-sangat renyah)

Selain itu fungsi dari kedua jenis larutan perendam memiliki kemampuan kerja yang hampir sama dalam melonggarkan jaringan ikat dengan ditandai oleh adanya proses pembengkakan pada komponen serabut kolagen kulit. Kolagen bersifat amfoter (mudah bereaksi dengan asam dan basa). Laju konversi kolagen juga dipengaruhi oleh suhu, waktu dan $\mathrm{pH}$ yang digunakan perlakuan (Kołodziejska et al., 2007). Tingkat kerenyahan dari suatu produk kerupuk lebih banyak dipengaruhi oleh proses penjemuran, penggorengan dan pengemasan (Sutejo dan Damayanti, 2002).

\section{Kesukaan}

Penilaian kesukaan panelis terhadap produk kerupuk dari bahan baku kulit kaki ayam selengkapnya disajikan pada Tabel 5.

Tabel 5. Nilai Rata-Rata Hasil Penilaian Kesukaan Kerupuk Kulit Kaki Ayam

\begin{tabular}{lccc}
\hline \multirow{2}{*}{ Jenis Ras Ayam } & \multicolumn{2}{c}{ Penilaian Kesukaan Menggunakan Jenis Larutan } & \multirow{2}{*}{ Rata-rata } \\
\cline { 2 - 3 } & \multicolumn{2}{c}{ Perendam } & \\
\hline Pedaging & $\mathrm{CH}_{3} \mathrm{COOH} 1 \%(\mathrm{v} / \mathrm{v})$ & $\mathrm{Ca}(\mathrm{OH})_{2} 1 \%(\mathrm{~b} / \mathrm{v})$ & $5,17^{\mathrm{c}}$ \\
Petelur & 5,23 & 5,11 & $4,70^{\mathrm{a}}$ \\
Buras & 4,95 & 4,45 & $5,02^{\mathrm{b}}$ \\
\hline \multicolumn{1}{l}{ Rata-rata } & 4,95 & 5,10 & \\
\hline
\end{tabular}

Keterangan: Skala penilaian kesukaan : 1-6 (tidak suka-sangat suka). Huruf yang berbeda pada kolom yang sama menunjukkan perbedaan yang nyata $(\mathrm{P}<0,05)$

Hasil analisis ragam pada data (Tabel 5) menunjukkan bahwa, perbedaan jenis ras ayam memiliki pengaruh yang nyata $(\mathrm{P}<0,05)$, sedangkan perbedaan jenis larutan perendam tidak memiliki pengaruh yang nyata $(\mathrm{P}>0,05)$ terhadap persepsi tingkat kesukaan panelis akan produk kerupuk kulit kaki ayam. Pengaruh yang nyata dari adanya perbedaan jenis ras ayam terhadap kesukaan panelis terkait dengan penampilan fisik dari kulit masing-masing jenis ras.

Kerupuk yang diproduksi dari bahan baku kulit kaki ayam jenis ras pedaging cenderung lebih disukai oleh panelis dibandingkan dengan kulit kaki ayam jenis ras petelur. Secara fisik kulit kaki ayam jenis ras pedaging berwarna kuning dan bersih dengan sisik yang halus, sedangkan buras dan ras petelur terlihat 
ISSN 1978-3000

berwarna gelap sampai hitam dengan sisik yang sangat kasar (Purnomo, 1992).

\section{SIMPULAN}

Perbedaan jenis ras ayam berpengaruh sangat nyata terhadap penampilan warna maupun kesukaan kerupuk kulit, namun tidak berpengaruh pada bau, cita rasa dan kerenyahan. Perbedaan jenis bahan perendam berpengaruh nyata terhadap cita rasa, namun tidak berpengaruh nyata terhadap persepsi bau, kerenyahan dan kesukaan kerupuk kulit. Panelis secara umum memberikan persepsi lebih baik pada produk kerupuk kulit dari jenis ras pedaging yang direndam dalam larutan basa $\left(\mathrm{Ca}(\mathrm{OH})_{2} 1 \% \mathrm{~b} / \mathrm{v}\right)$.

\section{DAFTAR PUSTAKA}

Anonimus. 2012. Statistik Peternakan dan

Kesehatan Hewan Tahun 2012.

Direktorat Jenderal Peternakan dan

Kesehatan Hewan. Kementerian

Pertanian RI, Jakarta.

Budiyanto, D. 1984. Pengaruh Umur terhadap Panjang, Lebar dan Ketebalan Kulit Sapi PO Jantan Kering. Skripsi Fakultas Peternakan Universitas Gadjah Mada, Yogyakarta.

Emil, M. 2004. Pengaruh Lama Perendaman Asam Asetat $\left(\mathrm{CH}_{3} \mathrm{COOH}\right) \quad 1 \%$ dan Kapur $\left(\mathrm{Ca}(\mathrm{OH})_{2}\right) \quad 1 \%$ terhadap Kualitas Organoleptik Kerupuk Kulit Kaki Ayam. Skripsi. Fakultas Peternakan Universitas Hasanuddin, Makassar.
Gasperz, V. 1991. Metode Perancangan Percobaan. CV. Armico, Bandung.

Kołodziejska, I., E. Skierka, M. Sadowska, W.Kołodziejski, and C.Niecikowska. 2007. Effect of extracting time and temperature on yield of gelatin from different fish offal. Food Chem 107 (2): 700-706. Muyonga, J.H., C.G.B. Cole, and K.G. Duodu. 2003. Fourier transform infrared (FTIR) spectroscopic study of acid soluble collagen and gelatin from skins and bones of young and adult Nile perch (Lates niloticus). Food Chemistry 86 (3): 325-332.

Purnomo, E. 1992. Penyamakan Kulit Kaki Ayam. Kanisius, Yogyakarta.

Purnomo, E. 1992. Penyamakan Kulit Reptil Reptil. Kanisius. Yogyakarta.

Soekarto, S.T dan M. Hubeis. 1993. Metodologi Penelitian Organoleptik. Program Studi Ilmu Pangan, IPB, Bogor.

Son, S.M., K.D. Mon, and C.Y. Lee. 2000. Rhubarb juice as natural anti browning agent. Journal of Food Science (65): 1285-1289.

Sutejo, A dan W. Damayanti. 2002. Rambak Kaki Ayam. PT Trubus Agrisarana, Surabaya.

Tyler, J.H and R.D. Gregory. 2005. An expeditions, high yield construction of the food aroma compound 6-acetyl-1,2,3,4tetrahydropyridine and 2-4acetyl1pyrrolyne . Journ Org Chem 70 (26): $10872-10874$. 
Verheul, M., S.P.F.M. Roefs and C.G. de Kruif. 1998. Kinetics of heatinduced aggregation of $\beta$ lactoglobulin. J of Agric and Food Chem (46): 896-903.

Wang, L., M.A.E.Auty, A.Rau, J.F.Kerry and J.P Kerry. 2008. Effect of $\mathrm{pH}$ and addition of corn oil on the properties of gelatin based biopolymer film. J of Food Engineering, 90 (1): 11-19.

Zhang, Y., W. Liu, G.Li, B.Shi, Y. Miao and $\mathrm{X} . \mathrm{Wu}$. 2007. Isolation and partial characterization of pepsinsoluble collagen from the skin of grass carp (Ctenopharyngodon idella). Food Chemistry (103): 906-912. 